\title{
MYCOPHENOLATE MOFETIL IN TREATMENT OF CHRONIC GLOMERULONEPHRITIS
}

\author{
Liliya O. Zub \\ Institute of Nephrology, Kyiv, Ukraine
}

\section{SUMMARY:}

This article studies the action of mycophenolate mofetil (Cell-Cept) on the rates of cell immunity, the level of proteinuria. There was also determined its safe usage in patients with chronic glomerulonephritis concomitant by nephrotic syndrome and the preserved renal function. Cell-Cept was proved to be successfully used in the immunosuppressive therapy of patients with membranous glomerulonephritis, as it is easily endured by patients and it has no considerable side effects. No valuable positive alterations were found in patients with focal segmental glomerulosclerosis after CellCept administration during 6 months.

\section{INTRODUCTION}

During the last 5 years the incidence of chronic glomerulonephritis grows in Ukraine. In 2003 chronic glomerulonephritis was registered in 30652 patients and its distribution reached 80.8 per 100000 adults [1].

Chronic glomerulonephritis is the most frequent cause in development of chronic renal failure and invalidism of nephrologic patients. The steroidal and cytostatic treatment frequently causes severe side effects [2]. In some morphological variants of chronic glomerulonephritis corticosteroids are non effective, and cytostatics inhibit not only the immune cells but others too (blood-forming, gonadal, intestine epithelial cells).

Therefore recently much attention is paid in patients with chronic glomerulonephritis concomitant by nephrotic syndrome to the study of probable usage of mycophenolate mofetil (Cell-Cept), the cytostatic effect of which is mainly limited by lymphocytes, that provides immunosuppression without inhibition of bone marrow cells and, as a result, the satisfactory acceptability of the drug, the smaller spectrum and incidence of side effects [3, 4, 5, 6, 8, 13, 17].

Cell-Cept is a specific selective inhibitor of inosine monophosphate dehydrogenase which participates in synthesis of purine and exerts the basic cytostatic action on lymphocytes, as the proliferation of $\mathrm{T}$ - and $\mathrm{B}$ - lymphocytes mainly depends on the purine synthesis $[3,7,11,13,15]$.

Nowadays there is no enough data about Cell-Cept application in the treatment of immuno-mediated pathology, except for the successful application of this drug in transplantology. But even the small number of the publicated results both experimental $[7,12]$ and clinical $[4,9,10,14,16]$ testifies to the expediency of studying the efficacy of CellCept in prevention of progressing renal insufficiency in chronic glomerulonephritis.

The aim of this study was to investigate the effect of Cell-Cept on the indices of cellular immunity, the proteinuria level, and to define its harmless usage in patients with chronic glomerulonephritis concomitant by nephrotic syndrome and the preserved renal function.

\section{MATERIALS AND METHODS}

Eighteen patients with chronic glomerulonephritis concomitant by nephrotic syndrome and preserved renal function were studied. The diagnostic verification was based on the evaluation of patients' complaints, anamnesis, clinical and laboratory findings, and on the instrumental examination of kidneys, the evidences of renal punch biopsy. The group of patients consisted of 11 men and 7 women aged from 21 to 59 years. The comparative group included patients with chronic glomerulonephritis concomitant by nephrotic syndrome before Cell-Cept administration. Cell-Cept was prescribed to the majority of patients under study after the failed treatment with other immunosuppressants (Prednisolone, Cyclophosphan). The patients were selected at random and examined in dynamics after 3 and 6 months of Cell-Cept therapy.

The punch biopsy of kidneys revealed 13 patients with membranous, 2 - with mesangioproliferative glomerulonephritis and 3 - with focal segmental glomerulosclerosis.

Cell-Cept was prescribed at a dose of $2 \mathrm{~g}$ per day. The number of lymphocytes, which expressed on membranes the corresponding antigens (CD4, CD8, CD54, CD95), was determined in patients' blood with the help of monoclonal antibodies of the companies "Сорбент" (Russia) and "Coltage" (USA) using the method of indirect immunofluorescence. The level of pro-inflammatory cytokine interferon- $\Gamma$ (INF- $\gamma$ ) and anti- inflammatory interleukin-10 (IL10) was determined through the immunoenzymatic method using the test system IMMUNOTECH (France).

Every patient underwent the urine analysis for the level of diurnal proteinuria, as the latter prognosticates the continued progress of chronic glomerulonephritis, activating the development of interstitial fibrosis.

The Student's t-test was used for statistical processing of the data. 


\section{RESULTS AND DISCUSSION}

The resultant data showed that by the end of the 3rd month of the Cell-Cept therapy the majority of patients had decreased 2 times their proteinuria levels and appreciably reduced edema without diuretics (Fig. 1).

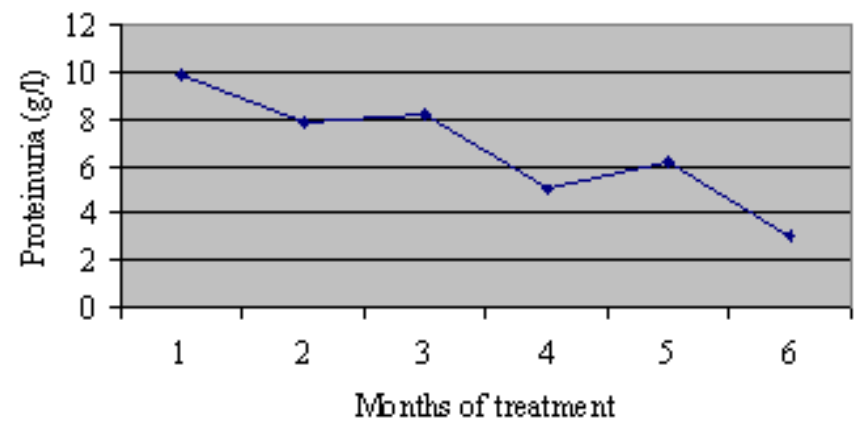

Fig. 1. Dynamics of $24 \mathrm{~h}$ proteinuria during 6 month treatment with Cell-Cept in patients with membranous glomerulonephritis.

The general state of patients and their quality of life was much better.

In studying the CD-markers of T-lymphocytes the positive dynamics of the immune response was noted even after the 3rd month of treatment with Cell-Cept and the approach of these indices to normal after 6 months of its application was also registered. Thus, if the level of CD54 activator of T-lymphocytes in the control group was $28,4+0,9$ (normal 16,9+0,9) and that of pro-apoptotic factor CD95 was $19,8+0,6$ (normal $11,3+0,6$ ) then by the end of the sixth month of treatment CD54 and CD95 demonstrated verisimilar change $-18,7+0,6$ and 12,5+0,4, respectively (Table 1.).

Table 1. Changes of immune indices under Cell-Cept effect in patients with chronic glomerulonephritis concomitant by nephrotic syndrome (n, M+m)

\begin{tabular}{|c|c|c|c|}
\hline \multirow{2}{*}{$\begin{array}{c}\text { Immune } \\
\text { indices }\end{array}$} & \multicolumn{3}{|c|}{ Groups of patients } \\
\cline { 2 - 4 } & Control & $\begin{array}{c}\text { Cell-Cept } \\
\text { 3 months } \\
(\mathrm{n}=13)\end{array}$ & $\begin{array}{c}\text { Cell-Cept } \\
6 \text { months } \\
(\mathrm{n}=13)\end{array}$ \\
\hline CD4 (\%) & $24,3+1,1$ & $28,1+1,2$ & $29,4+1,4$ \\
\hline CD8 (\%) & $30,1+1,3$ & $27,2+1,3$ & $18,4+1,1^{*}$ \\
\hline CD54 (\%) & $28,4+0,9$ & $24,2+0,6$ & $18,7+0,6^{*}$ \\
\hline CD95 (\%) & $19,8+0,6$ & $17,5+1,0$ & $12,5+0,4^{*}$ \\
\hline INF- $\gamma(\mathrm{pg} / \mathrm{ml})$ & $97,8+1,1$ & $77,2+1,2^{*}$ & $49,5+1,3^{*}$ \\
\hline IL-10 (pg/ml) & $67,7+1,9$ & $95,8+2,2^{*}$ & $106,9+2,5^{*}$ \\
\hline
\end{tabular}

Note: $* *_{-}<0,05$ compared to control
As the Table shows, CD4 and CD8 also statistically changed by the end of the 6 month treatment.

The INF- $\gamma$ indices decreased 2 times by the end of the 6 month therapy but remained still far from normal (normal 20,2+1,1). Probably, the long-term interstitial infiltration stipulates the stable INF- $\gamma$ increase in patients with chronic glomerulonephritis. On the other hand, the INF- $\gamma$ increase during the period, when the sings of sclerosing in renal tissue appear, can indicate its antisclerotic action, that is demonstrated by some experimental works.

The level of anti-inflammatory IL-10 increases twice but still remains far from normal (normal $-200,1+3,4$ ).

Analyzing separately the patients with mesangioproliferative glomerulonephritis and those with focal segmental glomerulosclerosis, it can be noted that in the patients with mesangioproliferative glomerulonephritis the changes in the immune indices and proteinuria level statistically did not differ from the indices of patients with membranous glomerulonephritis (Figs 2, 3).

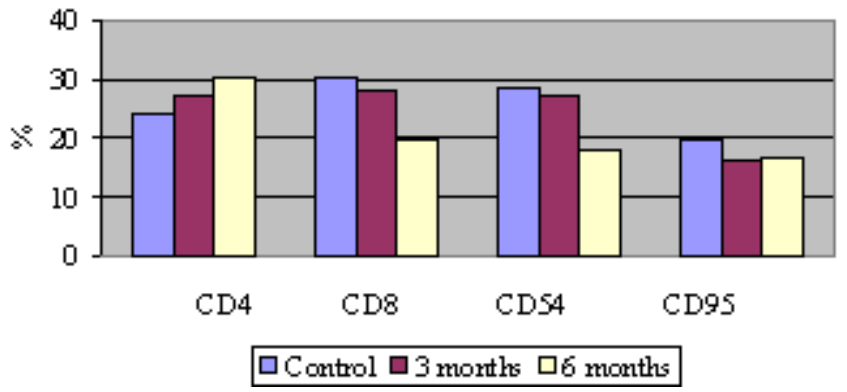

Fig. 2. Dynamics of immune indices depending on the term of Cell-Cept application in patients with mesangioproliferative glomerulonephritis .

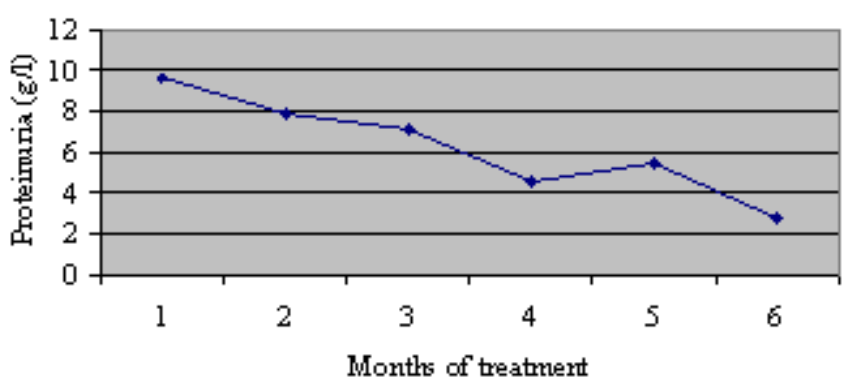

Fig. 3. Dynamics of $24 \mathrm{~h}$ proteinuria during 6 month treatment with Cell-Cept in patients with mesangioproliferative glomerulonephritis.

But the patients with focal segmental glomerulosclerosis experienced some improvement, though the changes in the immunity indices and $24 \mathrm{~h}$ proteinuria statistically differed from the control group (Figs 4, 5). 


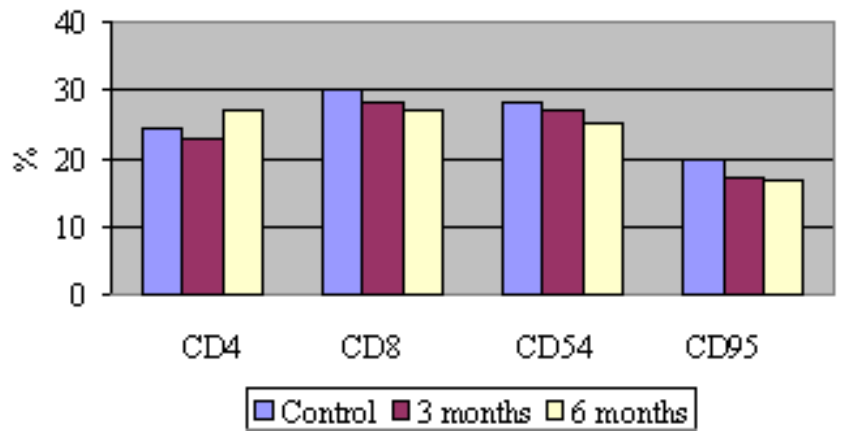

Fig. 4. Dynamics of immune indices depending on the term of Cell-Cept application in patients with focal segmental glomerulosclerosis.

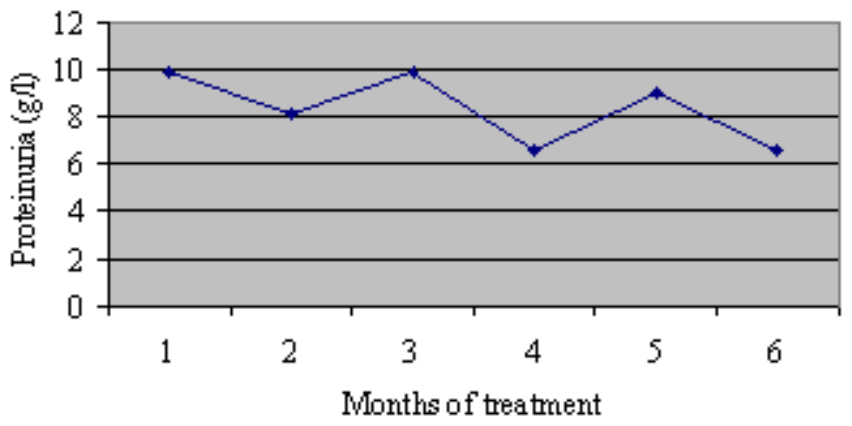

Fig. 5. Dynamics of $24 \mathrm{~h}$ proteinuria during 6 month treatment with Cell-Cept in patients with focal segmental glomerulosclerosis.
It should be noted that a complication from intake of Cell-Cept was seen in 1 patient, manifested by pain and dysfunctions in joints. The rest of patients were free of side effects and complications.

So, under the effect of Cell-Cept during 6 months of its application the impaired immune status of patients with chronic glomerulonephritis concomitant by nephrotic syndrome improves and this is mostly visible in patients with membranous glomerulonephritis. The correction of pro-inflammatory and anti- inflammatory immune factors promotes the drop in activity of inflammatory process in kidneys, that is testified by statistical reduction of proteinuria.

\section{CONCLUSIONS}

1. Cell-Cept can be successfully used in the immunosuppressive therapy of patients with membranous glomerulonephritis complicated by nephrotic syndrome as a remedy of choice.

2. Patients with focal segmental glomerulosclerosis showed no considerable positive changes after 6 months intake of Cell-Cept.

3. Cell-Cept is easily endured by patients: no considerable complications or side effects were found after its 6 month application.

\section{REFERENCES}

1. Колесник М.О., Сайдакова Н.О. Нефрологічна служба в 2003 році: здобутки, проблеми та шляхи пх вирпшення. Укр. Журнал нефрологіп та діалізу. - 2004. - No. 1.- C.12 - 16. [in Ukrainian]

2. Нефрология. Руководство для врачей. Под ред. И. Е. Тареевой. М.: Медицина, 2000. - С. 448 - 453. [in Russian]

3. Allison A. C., Eugni E. M. Purine metabolism and immunosuppressive effects of mycophenolate mofetil (MMF). Clin. Transplant. -1996. -No.10. - P. 77-84.

4. Briggs WA, Choi MJ, Scheel PJ Jr. Successful mycophenolate mofetil treatment of glomerular disease. Am J Kidney Dis. 1998 Feb;31(2):213-7. [Pubmed]

5. Briggs WA, Choi MJ, Scheel PJ
Jr. Follow-up on mycophenolate treatment of glomerular disease. Am J Kidney Dis. 1998 May;31(5):898-9. [PubMed]

6. Chan TM, Li FK, Tang CS, Wong RW, Fang GX, Ji YL, et al. Efficacy of mycophenolate mofetil in patients with diffuse proliferative lupus nephritis. Hong Kong-Guangzhou Nephrology Study Group. N Engl J Med. 2000 Oct 19;343(16):1156-62. [PubMed] [CrossRef]

7. Chanaud N.P., Vistica B.P., Eugni E. M., Nussenblatt R.B., Allison A. C., Gery I. Inhibition of experimental autoimmune uveoretinitis by mycophenolate mofetil, an inhibitor of purine metabolism. Exp Eye Res. 1995; 61: 429-434.

8. Choi MJ, Eustace JA, Gimenez et al. Mycophenolate mofetil treatment of primary glomerular diseases. Kidney Int. 2002; 61: 1089-1114

9. Dooley M.A., Cosio F.G., Nachman P.H. et al. Mycophenolate mofetil therapy in lupus nephritis: clinical observations. J Am Soc Nephrol. 1999; 10: 833-839.

10. Day C.J., Cockwell P., Lipkin $\mathrm{G}, \mathrm{W}$. et al. Mycophenolate mofetil in the treatment of resistant idiopathic nephrotic syndrome. Nephrol Dial Transplant. 2002 Nov; 17 (11): 20112013.

11. European Mycophenolate Mofetil Cooperative Study Group: Placebo-controlled study of mycophenolate mofetil combined with cyclosporin and corticosteroids for prevention of acute rejection. Lancet. 1995 May 27;345(8961):1321-1325. [CrossRef] 
12. Hao L, Chan SM, Lafferty KJ. Mycophenolate mofetil can prevent the development of diabetes in BB rats. Ann N Y Acad Sci. 1993 Nov 30;696:328-32. [PubMed] [CrossRef]

13. Glicklich D, Acharya A. Mycophenolate mofetil therapy in lupus nephritis refractory to intravenous cyclophosphamide. Am J Kidney Dis. 1998; 32(2):318-322.

14. Li LS, Hu WX, Chen HP, Liu ZH. Comparison of mycophenolate mofetil vs cyclophosphamide pulse therapy in the induction treatment of severe diffuse proliferative lupus nephritis in Chinese population. J Am Soc Nephrol. 12000; 89A (Abstract A0486).

15. Ojo AO, Meier-Kriesche HU, Hanson JA, et al. Mycophenolate mofetil reduces late renal allograft loss independent of acute rejection. Transplantation 2000; 69: 2405-2409.

16. Pesavento T.E., Bay W.H., Agarwal G. et al. Mycophenolate therapy in frequently relapsing minimal change disease that has failed cyclophosphamide therapy. Am J. Kidney Dis. 2004: 43 (3) :3-6.

17. Sintchak MD, Fleming MA, Futer O, Raybuck SA, Chambers SP, Caron PR, et al. Structure and mechanisms of inosine monophosphate dehydrogenase in complex with the immunosuppressant mycophenolic acid. Cell. 1996; 85(6):921-930. 